\title{
A Tolnai-hegyhát gyertyános-tölgyesei (Corydali pumilae-Carpinetum Kevey 2008)
}

\author{
KEVEY Balázs ${ }^{1}$, HORVÁTH András ${ }^{2}$ és LENDVAI Gábor ${ }^{3}$ \\ ${ }^{1}$ Pécsi Tudományegyetem, Ökológiai Tanszék, 7624 Pécs, Ifjúság u. 6.; \\ keveyb@gamma.ttk.pte.hu \\ ${ }^{2}$ Vak Bottyán Általános Iskola és Gimnázium, 7081 Simontornya, Hunyadi u. 15.; \\ horvath.a.zs@gmail.com \\ 37000 Sárbogárd, Tompa Mihály u.38/C; gaborlendvai@hotmail.com
}

Elfogadva: 2019. május 7.

Kulcsszavak: Délnyugat-Magyarország, erdei löszvegetáció, szüntaxonómia.

Összefoglalás: Jelen tanulmány a Dél-Dunántúl északkeleti peremén levő Tolnai-hegyhát gyertyános állományainak cönológiai jellemzése 50 felvétel alapján. Megvizsgáltuk e gyertyánosok társulástani kapcsolatát a Tolnai-hegyhát zárt lösztölgyeseivel (Pulmonario mollis-Quercetum roboris). A vizsgálat során kiderült, hogy a gyertyánosokban a Fagetalia fajok és az európai flóraelemek dominálnak, míg a zárt száraz tölgyesekben a Quercetea pubescentis-petraeae fajok, valamint a szubmediterrán és a kontinentális flóraelemek jutnak vezető szerephez. Az összehasonlító elemzés során bebizonyosodott, hogy a Tolnai-hegyhát gyertyánosai közelebbi rokonságot mutatnak a Dunántúli-középhegység gyertyános-tölgyeseivel (Keleti-Bakony, Velencei-hegység), mint a DélDunántúliakkal (Nyugat-Mecsek, Völgység). A vizsgált gyertyános-tölgyeseket ezért a „Corydali pumilae-Carpinetum KeVEY 2008” nevü asszociációval azonosíthatjuk, amely a Carpinenion betuli IsSLER 1931 alcsoportba (suballiance) sorolható.

\section{Bevezetés}

A Tolnai-hegyhát flóráját és vegetációját PILlich sen. (1927) és Pillich jun. (1930a, b, c) óta gyakorlatilag nem kutatták. Erdeinek cönológiai felmérését 2004-ben kezdtük el. Első ide vonatkozó cikkünk a zárt lösztölgyeseket (Pulmonario mollis-Quercetum roboris) foglalja magába (KEVEY et al. 2018). A tatárjuharos-tölgyesek (Aceri tatarici-Quercetum roboris) felvételi anyagának nyomdai előkészítése folyamatban van. A gyertyános-tölgyesek (Corydali cavae-Carpinetum) cönológiai felmérését 2006 és 2017 között végeztük, s jelen tanulmányban a társulást 50 cönológiai felvétel alapján jellemezzük. 


\section{Anyag és módszer}

\section{A kutatási terület jellemzése}

Kutatási területünk a Tolnai-hegyhát, amely a Dél-Dunántúl flóravidékének (Praeillyricum) északkeleti peremén terül el. A táj BORHIDI (1961) klímazonális térképe szerint az erdőssztyepp zónába tartozik, ezért a völgyekben található gyertyános-tölgyesek (Corydali cavae-Carpinetum) extrazonálisnak tekinthetők.

2006 és 2017 között alaposan bejártuk a táj erdeit. Felmérésre érdemes erdőket csak a Tolnai-hegyhát északi peremén találtunk Simontornya, Kisszékely és Nagyszékely határában. A vizsgált állományok 130-180 m tengerszint feletti magasságban fordulnak elő. Az alapkőzet mindenütt lösz. E gyertyános-tölgyesek néhol pár hektárnyi kiterjedésűek is lehetnek (Kisszékely: Dukai-hegy; Pálfa: Kis-erdő; Simontornya: Csirka-völgy). Többségük a löszdombok enyhe (2-5 fokos), vagy közepesen meredek (15-25 fokos) északias kitettségü lejtőin, völgyoldalakon, illetve völgyaljakon található. Mikroklímájuk viszonylag hűvös és párás, talajuk pedig az üde tartományba sorolható.

\section{Alkalmazott módszerek}

A cönológiai felvételek a Zürich-Montpellier növénycönológiai iskola (BECKING 1957; BRAUN-BLANQUET 1964) hagyományos kvadrát-módszerével készültek. A felvételek táblázatos összeállítása, valamint a karakterfajok csoportrészesedésének és csoporttömegének számítása az „NS” számítógépes programcsomaggal (KeVEY és HiRmanN 2002) történt. A felvételkészítés és a hagyományos statisztikai számítások kissé módosított módszere KEVEY (2008) tanulmányában megtalálható. Az állományszerkezeti vizsgálatok során a szintek borítottságát és magasságát becsléssel állapítottuk meg. Hasonlóan jártunk el a fák törzsátmérőjének meghatározásakor is. Ez esetben csak a felső lombkoronaszint fáit vettük figyelembe, $s$ a leggyakoribb fák törzsátmérőjét becsültük. Amennyiben 1-1,5 m átmérőjü famatuzsálemek is voltak a felvett állományban, ezek száma alapján a becsült értéket $5-10 \mathrm{~cm}$-rel növeltük. A Syn-Tax 2000 programcsomag (PODANI 2001) segítségével sokváltozós elemzéseket is végeztünk. E téren bináris adatokon alapuló hierarchikus osztályozást (hasonlósági index: Baroni-Urbani-Buser; osztályozó módszer: teljes lánc és csoportátlag), és szintén bináris alapú ordinációt (hasonlósági index: Baroni-Urbani-Buser; ordinációs módszer: főkoordináta-analízis) készítettünk.

A fajok esetében KIRÁLY (2009), a társulásoknál pedig BORHIDI és KEVEY (1996), KEVEY (2008), illetve BoRHIDI és mtsai (2012), nómenklatúráját követjük. A társulástani és a karakterfaj-statisztikai táblázatok felépítése az újabb eredményekkel (Oberdorfer 1992; MuCina et al. 1993; KeVey 2008; BorHidi 
et al. 2012) módosított Soó (1980) féle cönológiai rendszerre épül. A növények cönoszisztematikai besorolásánál is elsősorban Soó (1964, 1966, 1968, 1970, 1973, 1980) Synopsis-ára támaszkodtunk, de figyelembe vettük az újabb kutatási eredményeket is (vö. BORHIDI 1993, 1995; HoRVÁtH et al. 1995).

Összehasonlítás céljából az elemzésekbe a Tolnai-hegyháton készült zárt lösztölgyes (Pulmonario mollis-Quercetum roboris) (KEVEY et al. 2018) felvételek mellett bevontuk a Bakony (Kevey ined.), a Velencei-hegység (Kevey ined.), a Nyugati-Mecsek (Kevey ined.) és a Völgység (Kevey ined.) területéről származó gyertyános-tölgyes (Corydali pumilae-Carpinetum, Asperulo taurinae-Carpinetum) felvételeket is.

\section{Eredmények}

\section{Szintezettség}

A Tolnai-hegyhát gyertyános-tölgyeseinek cönológiai felvételezéséből származó információkat az E1-E3. táblázat foglalja össze. A vizsgált állományok felső lombkoronaszintje az állomány korától és a termőhelyi viszonyoktól függően 22-30 m magas, és közepes, vagy erősebb záródást mutat (70-90\%). Állandó (K: IV-V) fája a Carpinus betulus, a Fraxinus excelsior, a Quercus cerris és a Quercus robur. Nagyobb tömegben (A-D: 3-5) előforduló fái a Carpinus betulus, a Fraxinus excelsior, a Quercus robur, ritkán pedig a Tilia tomentosa. E viszonylag zárt szintben lékek csak ritkán fordulnak elő. Az alsó lombkoronaszint magassága 15-22 $\mathrm{m}$, borítása pedig 20-50\%. Állandó (K: IV-V) fája csak az Acer campestre és a Carpinus betulus. Nagyobb tömeget (A-D: 3 ) csak a Carpinus betulus képez.

A cserjeszint fejlettsége változó, olykor hiányozhat is. Magassága 1-3 m, borítása pedig 1-50\%. Állandó (K: IV) eleme csak az Acer campestre. Nagyobb tömeget (A-D: 3) is csak az Acer campestre, valamint ritkán a Staphylea pinnata képez. Az alsó cserjeszint (újulat) általában fejletlen, 1-25\% borítású. Állandó (K: IV-V) fajai egyes fák fiatal egyedei: Acer campestre, Carpinus betulus, Fraxinus excelsior, Quercus cerris. E szintben nagyobb tömegben (A-D: 3-4) előforduló faj nem akadt.

A gyepszint borítása $40-95 \%$. Állandó elemei (K: IV-V) a következők: Ajuga reptans, Anemone ranunculoides, Brachypodium sylvaticum, Bromus ramosus, Corydalis cava, Corydalis pumila, Dactylis polygama, Galium odoratum, Geranium robertianum, Geum urbanum, Glechoma hirsuta, Isopyrum thalictroides, Lapsana communis, Lilium martagon, Mercurialis ovata, Mercurialis perennis, Moebringia trinervia, Mycelis muralis, Polygonatum latifolium, Polygonatum multiflorum, Ranunculus ficaria, Rumex sanguineus, Stachys sylvatica, Stellaria holostea, Urtica dioica, Veronica sublobata, Viola reichenbachiana, Viola suavis. E szintben az alábbi lágyszárúak képeznek fáciest (A-D: 3-5): Anemone ranunculoides, Corydalis cava, Galium odoratum, Stellaria holostea, Vinca minor. 


\section{Fajkombináció \\ A sokváltozós statisztikai elemzések eredményei}

A Tolnai-hegyháton a gyertyános-tölgyesek mindenütt zárt száraz tölgyesekkel (Pulmonario mollis-Quercetum roboris) érintkeznek, ezért először e két aszszociáció összehasonlítását végeztük el.

A cluster-analízis dendrogramjain (1. és 2. ábra) ugyan két fő csoportosulás figyelhető meg, de a két társulás az átmeneti jellegű felvételek miatt nem vált el tökéletesen. Ezután a kétszer 50 felvételből álló elemzési anyagból eltávolítottuk az átmenetinek tartott felvételeket. A maradék 35 gyertyános-tölgyes és 31 száraz tölgyes felvétellel újra elvégeztük a clusteranalízist, amelynek eredményeként a két társulás felvételei már két szépen elkülönült csoportokba rendeződtek (3. és 4. ábra).

\section{Állandósági osztályok eloszlása}

A szelekció során megmaradt 35 gyertyános-tölgyes felvételben 22 konstans és 11 szubkonstans faj szerepel az alábbiak szerint: $\mathrm{K} \mathrm{V}$ : Acer campestre, Ajuga reptans, Anemone ranunculoides, Brachypodium sylvaticum, Bromus ramosus agg., Carpinus betulus, Corydalis cava, Corydalis pumila, Dactylis polygama, Fraxinus excelsior, Geranium robertianum, Geum urbanum, Lilium martagon, Mercurialis perennis, Polygonatum latifolium, Quercus cerris, Quercus robur, Ranunculus ficaria, Rumex sanguineus, Stellaria holostea, Veronica sublobata, Viola reichenbachiana. - K IV: Galium odoratum, Glechoma hirsuta, Isopyrum thalictroides, Lapsana communis, Mercurialis ovata, Moehringia trinervia, Mycelis muralis, Stachys sylvativa, Tilia tomentosa, Urtica dioica, Viola suavis (E1. táblázat). A társulásból továbbá 20 akcesszórikus (K: III), 25 szubakcesszórikus (K: II) és 85 akcidens (K: I) faj került elő (E1. táblázat). Az állandósági osztályokat tekintve tehát az akcidens (K: I) elemek mellett a konstans (K: V) fajoknál mutatkozik egy gyengébb második maximum (5. ábra).

\section{Karakterfajok aránya}

A vizsgált gyertyános-tölgyesekben jelentős szerepet játszanak a mezofil lomberdei elemek (Fagetalia incl. Alnion incanae, Carpinenion, Tilio-Acerenion és Aremonio-Fagion). E növények $23,5 \%$ csoportrészesedést és $43,7 \%$ csoporttömeget érnek el. Arányuk tehát több mint kétszer akkora, mint a zárt lösztölgyesekben (Pulmonario mollis-Quercetum roboris) (E1. és E4. táblázat; 6. ábra).

A gyertyános-tölgyesek felépítésében a száraz tölgyesek elemei (Quercetea pubescentis-petraeae incl. Quercetalia cerridis, Quercion farnetto, Quercion pet- 


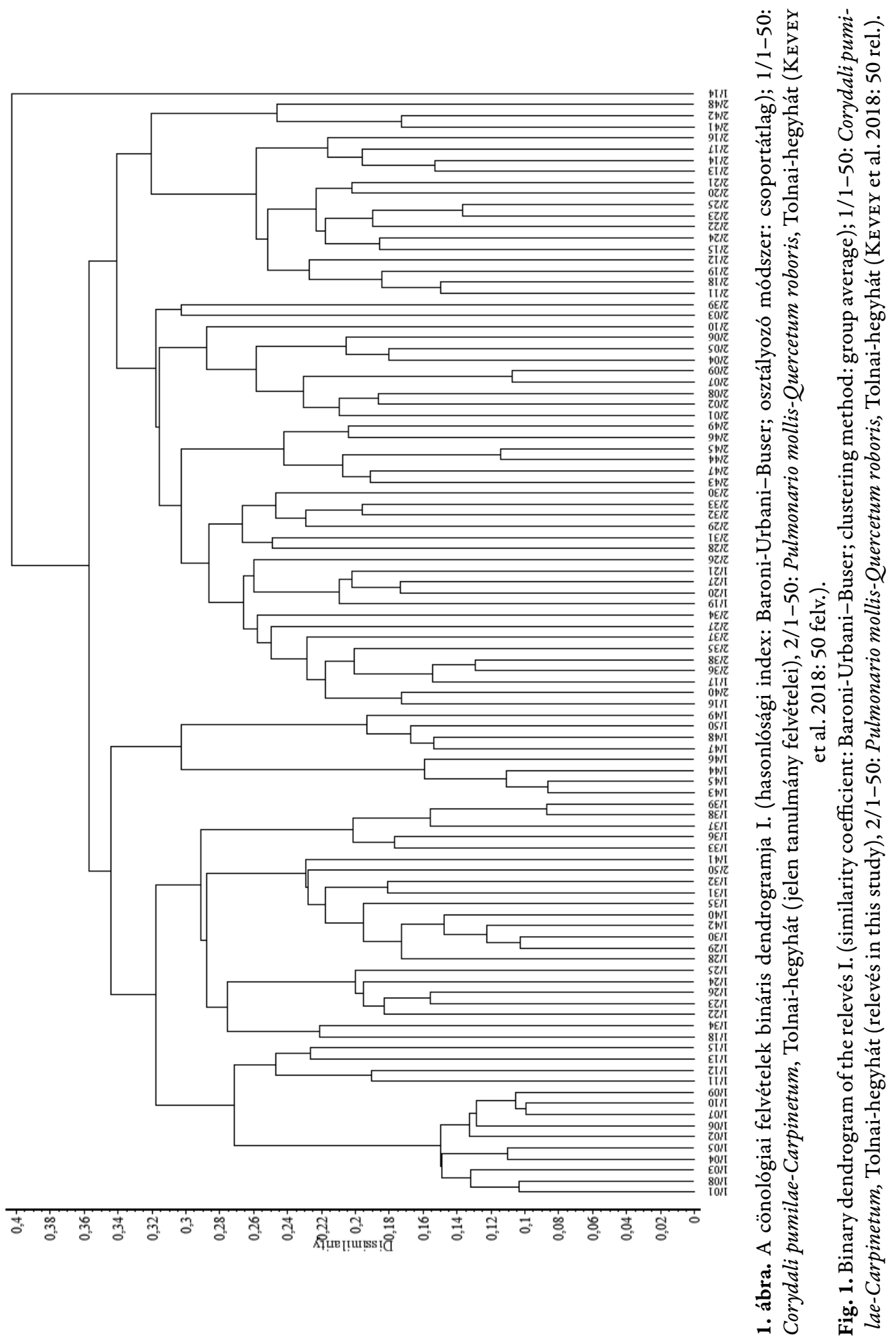


Kevey B. et al.

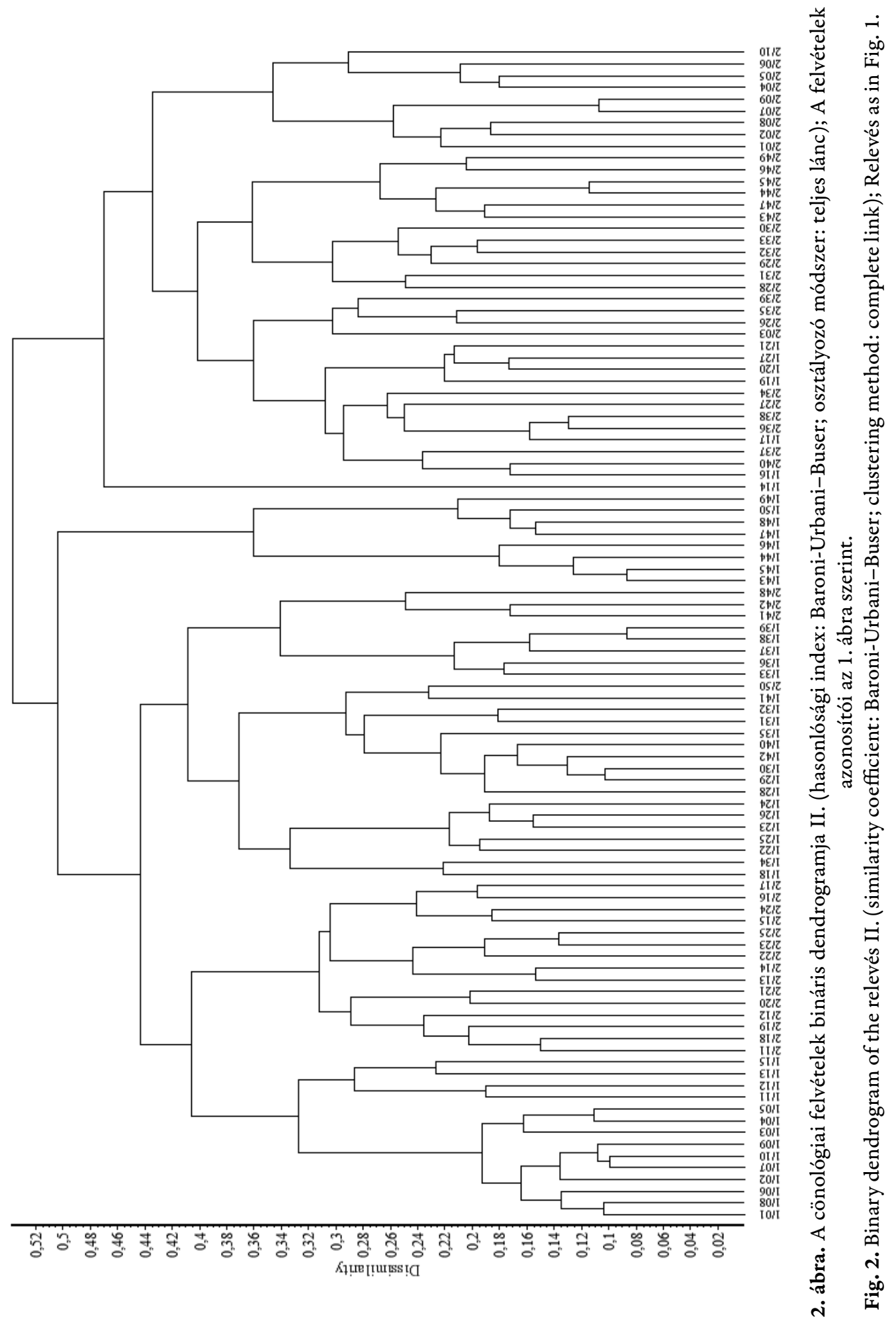




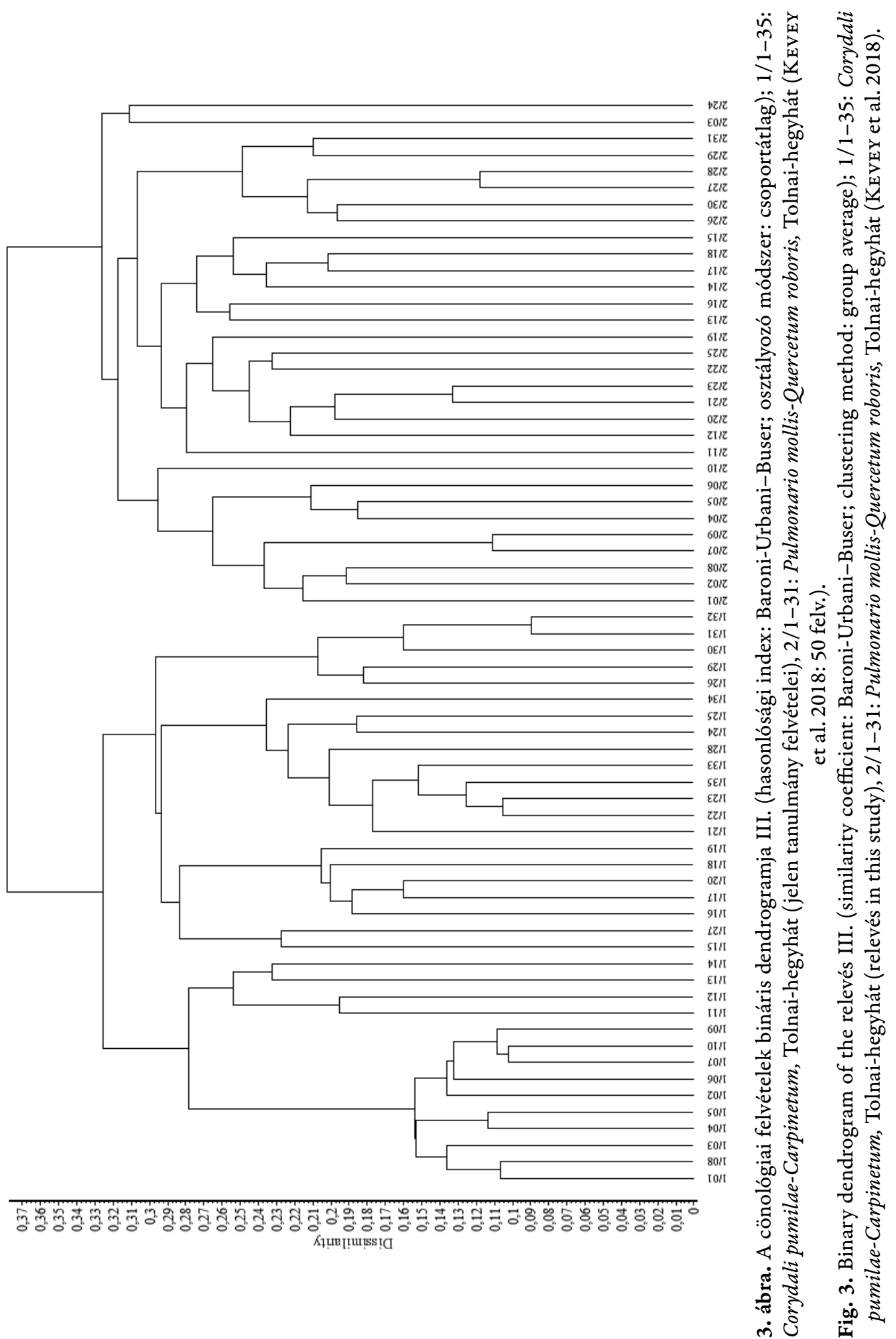


Kevey B. et al.

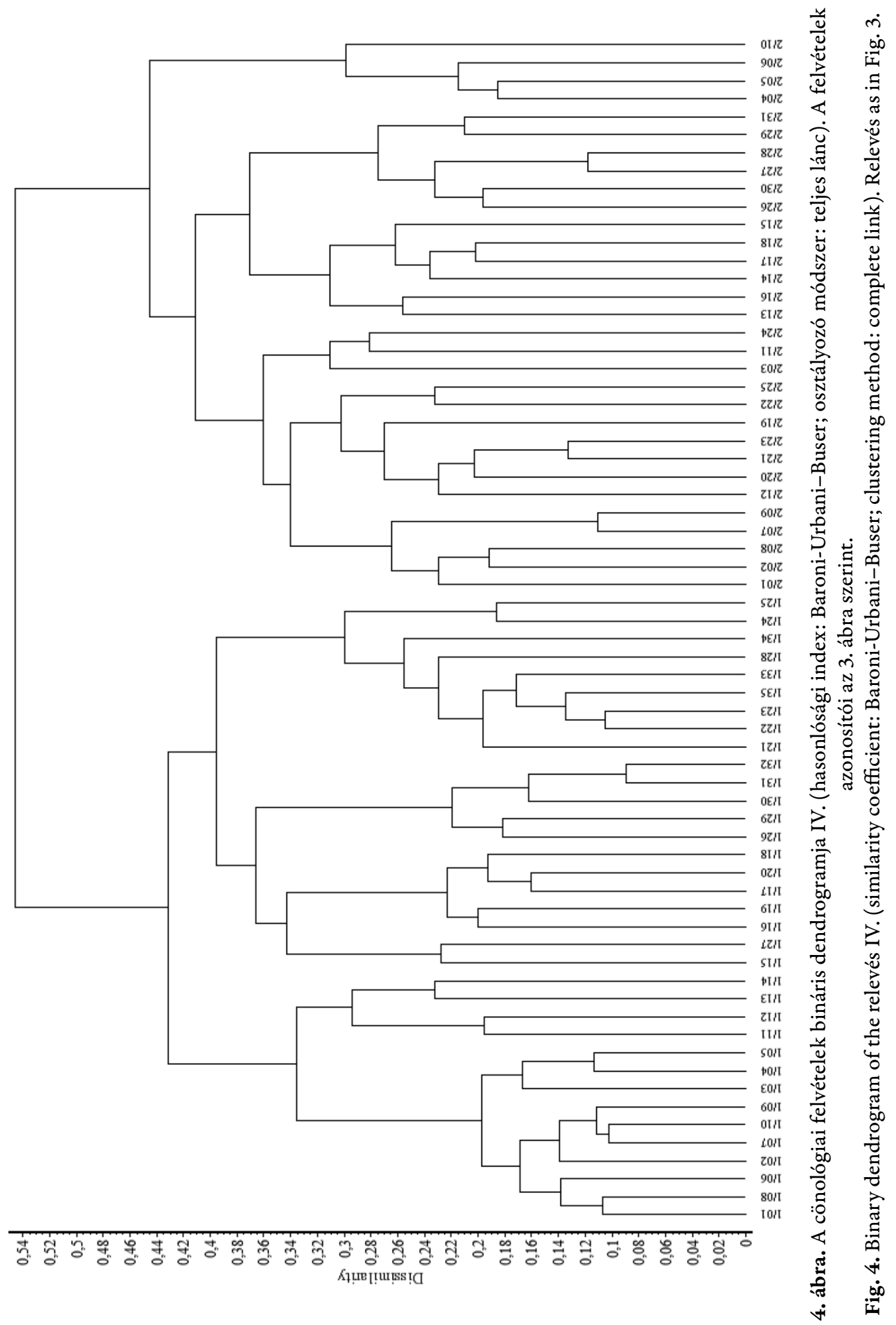


raeae, Aceri tatarici-Quercion) szintén meghatározóak. E Quercetea pubescentispetraeae s. 1. elemek $23,8 \%$ csoportrészesedést és $13,9 \%$ csoporttömeget mutatnak (E1. és E4. táblázat; 7. ábra). Arányuk ennek ellenére lényegesen alacsonyabb, mint a zárt lösztölgyesekben (Pulmonario mollis-Quercetum roboris).

\section{Flóraelemek aránya}

A vizsgált gyertyános-tölgyesekben a flóraelemek közül az európai (incl. közép-európai) fajok a leggyakoribbak, csoportrészesedésük 44,5\%, csoporttömegük pedig $81,6 \%$. Ez az arány jóval magasabb, mint a zárt lösztölgyesekben (Pulmonario mollis-Quercetum roboris, E5. táblázat; 8. ábra).

A szubmediterrán elemek esetében fordított a helyzet. Ezek ugyanis a gyertyános-tölgyesekben csak 12,4\% csoportrészesedést és 6,5\% csoporttömeget mutatnak. Arányuk így jóval alacsonyabb, mint a zárt lösztölgyesekben (Pulmonario mollis-Quercetum roboris, E5. táblázat; 9. ábra).

Végül érdemes szemügyre venni a kontinentális (incl. szubkontinentális és pontusi) flóraelemeket, amelyek csoportrészesedése mindössze 4,7\%, csoporttömege pedig $1,8 \%$. Arányuk ennek megfelelően jóval alacsonyabb, mint a zárt lösztölgyesekben (E5. táblázat, 10. ábra).

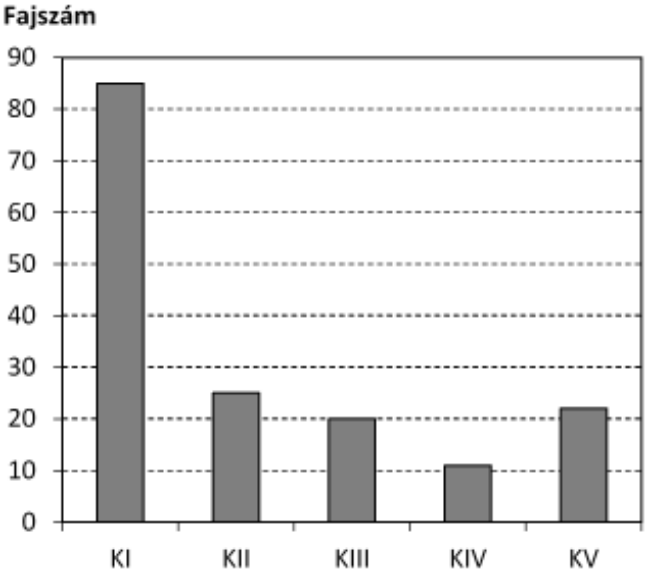

5. ábra. Az állandósági osztályok eloszlása a Tolnai-hegyhát gyertyános-tölgyeseiben (Corydali cavae-Carpinetum).

Fig. 5. Distribution of constancy classes of the Corydali cavae-Carpinetum forests of Tolnaihegyhát.

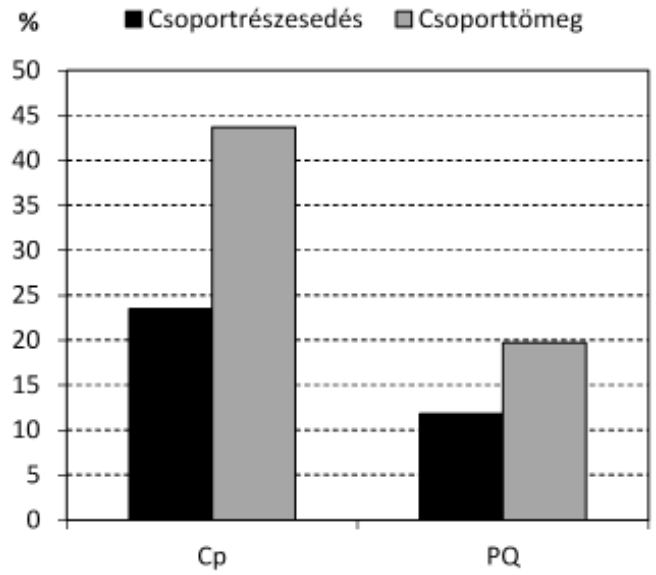

6. ábra. A Fagetalia fajok aránya. Cp: Corydali pumilae-Carpinetum, Tolnai-hegyhát (jelen tanulmány felvételei: 35 felv.), PQ: Pulmonario mollis-Quercetum roboris, Tolnai-hegyhát (KEVEY et al. 2018: 31 felv.).

Fig. 6. Percentage of species characteristic of the order Fagetalia. Cp: Corydali pumilae-Carpinetum, Tolnai-hegyhát (relevés in this study: 35 rel.), PQ: Pulmonario mollis-Quercetum roboris,

Tolnai-hegyhát (Kevey et al. 2018: 31 rel.). 


\section{A gyertyános-tölgyesek és a zárt lösztölgyesek differenciális fajai}

A Tolnai-hegyhát gyertyános-tölgyesei és zárt lösztölgyesei (Pulmonario mollis-Quercetum roboris) között számos olyan differenciális fajt találunk, amelyek állandósága legalább két fokozat különbséget mutat (E6. táblázat). Vannak

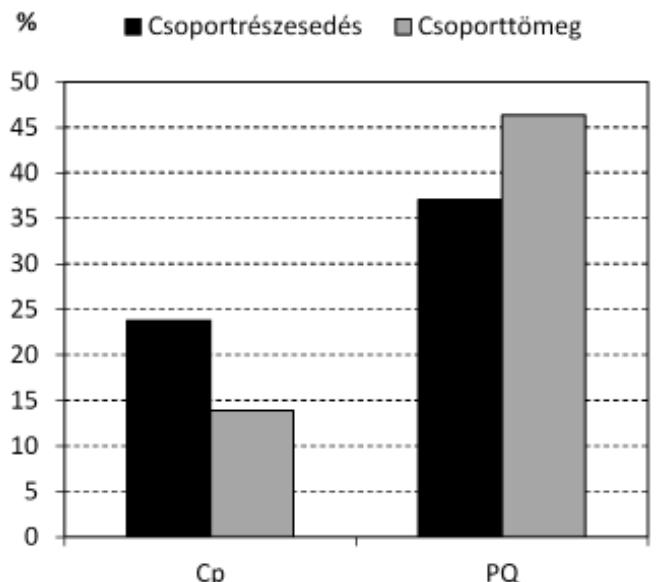

7. ábra. A Quercetea pubescentis-petraeae fajok aránya. A felvételek azonosítói a 6 . ábra szerint.

Fig. 7. Percentage of species characteristic of the class Quercetea pubescentis-petraeae. Relevés as in Fig. 6.

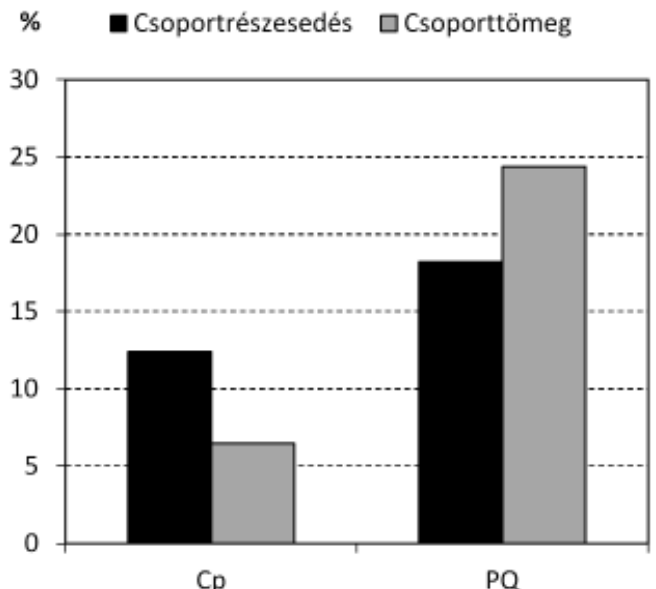

9. ábra. A szubmediterrán flóraelemek aránya. A felvételek azonosítói a 6 . ábra szerint.

Fig. 9. Percentage of sub-Mediterranean floristical elements. Relevés as in Fig. 6.

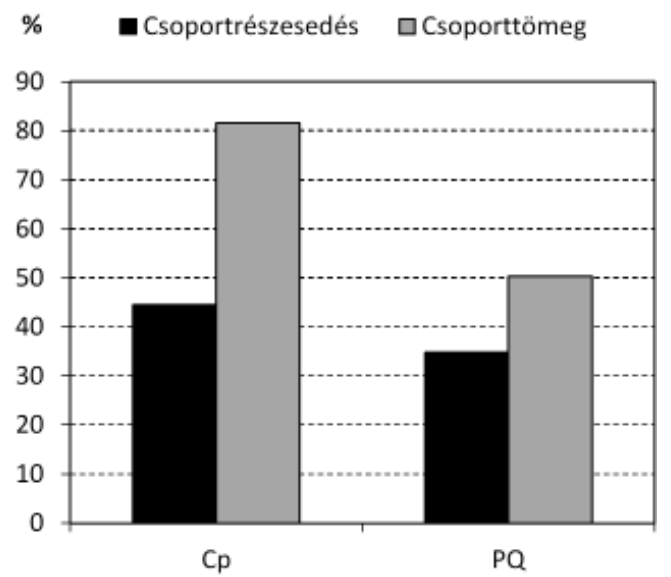

8. ábra. Az európai flóraelemek aránya. A felvételek azonosítói a 6. ábra szerint.

Fig. 8. Percentage of European floristical elements. Relevés as in Fig. 6.

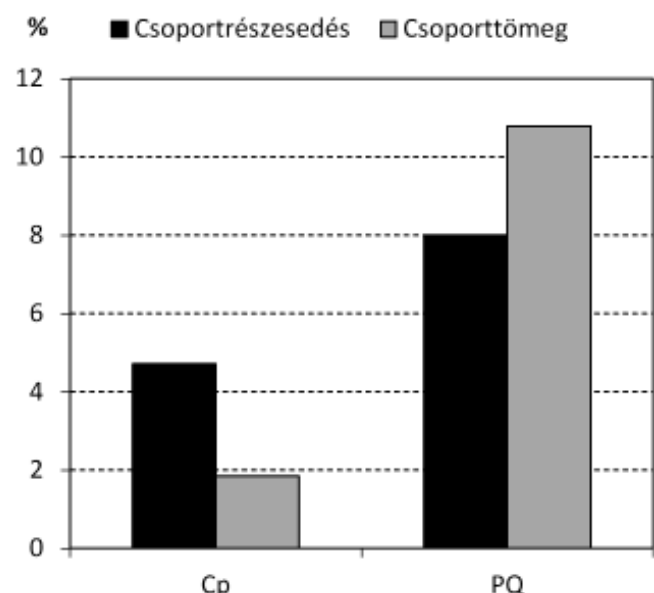

10. ábra. A kontinentális flóraelemek aránya. A felvételek azonosítói a 6 . ábra szerint.

Fig. 10. Percentage proportion of continental floristical elements. Relevés as in Fig. 6. 
ugyan közöttük közönséges növények is, de a gyertyános-tölgyesek differenciális fajainak mintegy kétharmada mezofil jellegü (Fagetalia) elem: Ajuga reptans, Carex sylvatica, Carpinus betulus, Gagea lutea, Galium odoratum, Isopyrum thalictroides, Lilium martagon, Mercurialis perennis, Moebringia trinervia, Mycelis muralis, Polygonatum multiflorum, Sanicula europaea, Stachys sylvatica, Staphylea pinnata, Viola reichenbachiana stb.

A zárt lösztölgyesekben ezzel szemben a differenciális fajok nagyobb részét a száraz erdők (pl. Quercetea pubescentis-petraeae, Quercetalia cerridis, Aceri tatarici-Quercion) karakterfajai képezik: Astragalus glycyphyllos, Brachypodium pinnatum, Buglossoides purpureo-coerulea, Carex michelii, Cornus mas, Dictamnus albus, Doronicum hungaricum, Piptatherum virescens, Quercuspubescens, Veratrum nigrum stb.

\section{Természetvédelmi vonatkozások}

A 35 cönológiai felvétel alapján ezekből a gyertyános-tölgyesekből 8 védett növényfaj került elö: K IV: Lilium martagon. - K III: Scilla vindobonensis. - K II: Doronicum hungaricum, Galanthus nivalis. - K I: Aconitum anthora, Cephalanthera damasonium, Epipactis helleborine agg., Neottia nidus-avis. Ezzel szemben, ha az 50 felvételt vesszük alapul, akkor a Lychnis coronaria (K: I) is elöfordul e gyertyános-tölgyesekben, míg a Doronicum hungaricum (K: III) és a Galanthus nivalis (K: I) állandósága más értéket kap.

A vizsgált gyertyános-tölgyesek (Corydali cavae-Carpinetum) kitünő állapotúak, hazai vegetációnk üde foltjait képezik. Ezen erdők jelenleg a Natura 2000 területek közé tartoznak. Botanikai-természetvédelmi értékeiknél fogva helyi jelentőségü védett területté történő nyilvánításuk folyamatban van.

Tájidegen elemek a felvett állományokban nem játszanak lényeges szerepet, hisz valamennyi fajuk akcidens (K: I): Ailanthus altissima, Celtis occidentalis, Gleditsia triacanthos, Juglans nigra, Juglans regia, Morus alba, Phytolacca americana, Pinus sylvestris, Robinia pseudo-acacia, Solidago gigantea, Stenactis annua. A Tolnai-hegyhát nagyobb részét azonban degradált erdők borítják, amelyekben e jövevényfajok sokkal gyakoribbak.

\section{Megvitatás}

Mivel a Tolnai-hegyhát gyertyános-tölgyesei szinte mindenütt zárt lösztölgyesekkel (Pulmonario mollis-Quercetum roboris) érintkeznek, elsősorban e két asszociáció egymáshoz való viszonyát kellett tisztáznunk. A sokváltozós elemzések (1-2. ábra) során az első lépésben nem sikerült a két asszociációt egyértelmüen elkülöníteni. Ennek oka elsősorban az, hogy közöttük számos átmeneti jelle- 
gű állomány van. Miután a vizsgálati anyagból eltávolítottuk az átmeneti állományokat, a két asszociáció egyértelmüen elkülönült (3-4. ábra). A további vizsgálatokra elsősorban ezt a szükített felvételi anyagot használtuk. Mind a karakterfajok (E3. táblázat, 6-7. ábra), mind pedig a flóraelemek (8-10. ábra) aránya bizonyítja a két asszociáció előfordulását a Tolnai-hegyháton.

Feltűnő, hogy a Tolnai-hegyhát gyertyános-tölgyeseiben viszonylag magas a Quercetea pubescentis-petraeae (incl. Quercetalia cerridis, Aceri tatarici-Quercion) elemek aránya. Ennek oka egyrészt ott van, hogy állományaikat mindenütt száraz tölgyesek (Pulmonario mollis-Quercetum roboris, Aceri tatarici-Quercetum pubescentis-petraeae) veszik körül. Másrészt BORHIDI (1961) klímazonális térképe szerint a Tolnai-hegyhát az erdőssztyep zónában foglal helyet, amely klimatikus szempontból is magyarázatot ad a Quercetea jellegü, extrazonális gyertyános-tölgyesek kialakulására.

Mindezeken túl érdemes megvizsgálni azt, hogy e gyertyános-tölgyesek milyen rokonsági kapcsolatban vannak a Dunántúli-középhegység és a DélDunántúl gyertyános-tölgyeseivel? Az összehasonlító elemzéssel kapott ordinációs diagramról (11. ábra) leolvasható, hogy a Tolnai-hegyhát gyertyánostölgyesei közelebb állnak a Dunántúli-középhegység (Keleti-Bakony, Velencei-hegység) gyertyános-tölgyeseihez, mint Dél-Dunántúl (Nyugati-Mecsek, Völgység) állományaihoz. Ez azért érdekes, mert a Dél-Dunántúl flóravidékének (Praeillyricum) gyertyános-tölgyeseit eddig az Aremonio-Fagion csoportba soroltuk. A felvételek alapján a Tolnai-hegyhát gyertyános-tölgyeseiből mindössze egyetlen Aremonio-Fagion karakterfaj került elö, a Tilia tomentosa. A Dunántúli-középhegység gyertyános-tölgyeseivel való rokonságot viszont a Corydalis pumila, a Piptatherum virescens és a Veratrum nigrum gyakori elöfordulása is bizonyítja. Ennek megfelelően a Tolnai-hegyhát gyertyános-tölgyeseit nem a dél-dunántúli Asperulo taurinae-Carpinetum-mal és a Helleboro dumetorum-Carpinetum-mal kell azonosítanunk, hanem a Dunántúli-középhegység Corydali pumilae-Carpinetum-ával. Az asszociáció helye a növénytársulások rendszerében az alábbi módon vázolható:

Divízió: Querco-Fagea Jakucs 1967

Osztály: Querco-Fagetea Br.-Bl. et Vlieger in Vlieger 1937 em. Borhidi in Borhidi et Kevey 1996

Rend: Fagetalia sylvaticae Pawłowski in Pawłowski et al. 1928

Csoport: Fagion sylvaticae Luquet 1926

Alcsoport: Carpinenion betuli Issler 1931

Asszociáció: Corydali pumilae-Carpinetum Kevey 2008 
Az erdőtársulás az olyan gyertyános-tölgyesek közé tartozik, amelyekben a mezofil (elsősorban Fagetalia) fajok mellett a xerofil (Quercetea pubescentispetraeae, Acerion tatarici-Quercion) elemek is jelentős szerepet játszanak. Ez az oka annak, hogy a Tolnai-hegyhát gyertyános-tölgyesei (Corydali pumilaeCarpinetum) és zárt lösztölgyesei (Pulmonario mollis-Quercetum roboris) között viszonylag sok az átmeneti jellegű állomány. Állandó Fagetalia jellegű fajai (K: IV-V) a következők: . Ezzel szemben a Quercetea pubescentis-petraeae (incl. Quercion petraeae és Aceri tatarici-Quercion) elemek közül csak a Mercurialis ovata és a Quercus cerris tartozik az állandó (K: IV-V) elemek közé. Ennek ellenére ezek a növények mégis jelentős szerepet játszanak a társulás felépítésében, hisz 23,8\% csoportrészesedést és 13,9\% csoporttömeget mutatnak, ugyanis sok közöttük az akcesszórikus (K: III), a szubakcesszórikus (K: II) és az akcidens (K: I) elem (E1. és E4. táblázat).

Uralkodó, vagy domináns fajok (A-D: 4-5) föleg a lombkoronaszintben (Acer campestre, Carpinus betulus, Corydalis cava, Fraxinus excelsior, Quercus robur), ritkán a gyepszintben (Corydalis cava) találhatók. A felső lombkoronaszintben a Carpinus betulus az Acer campestre-vel, a Fraxinus excelsior-ral, vagy a Quercus robur-ral több helyen kodomináns (A-D: 3-3) szerepet is betölt.

A gyertyános-tölgyesek (Corydali pumilae-Carpinetum) és a zárt lösztölgyesek (Pulmonario mollis-Quercetum roboris) közötti különbséget a differenciális fajok is jelzik. A gyertyános-tölgyesekből 23, a zárt lösztölgyesekből pedig 19 olyan faj került elő, amelyek a két asszociáció között legalább két állandósági fokozatnyi különbséget mutatnak (E6. táblázat).

A több területről származó felvételek sokváltozós elemzéséből (11. ábra) kiderült, hogy a Tolnai-hegyhát gyertyános-tölgyesei nem a Dél-Dunántúl, hanem a Dunántúli-középhegység gyertyános-tölgyeseivel mutatnak közelebbi rokonságot. Ennek oka nagyrészt az, hogy állományaiból - a Tilia tomentosa kivételével - hiányoznak az Asperulo taurinae-Carpinetum asszociációt jellemző Aremonio-Fagion és Quercion farnetto jellegü karakterfajok (Asperula taurina, Carex strigosa, Chaerophyllum aureum, Doronicum orientale, Helleborus dumetorum, Helleborus odorus, Hepatica nobilis, Knautia drymeia, Lonicera caprifolium, Luzula forsteri, Polystichum setiferum, Primula vulgaris, Ruscus aculeatus, Ruscus hypoglossum, Scutellaria altissima, Tamus communis). Ezzel szemben - ha nem is nagy fajszámmal - a Tolnai-hegyhát gyertyános-tölgyeseiben jelentősebb szerepet játszanak olyan növények, amelyek a Dunántúliközéphegységben jellemzőek, mint a Corydalis pumila, a Piptatherum virescens és a Veratrum nigrum (E1. táblázat). 
a)

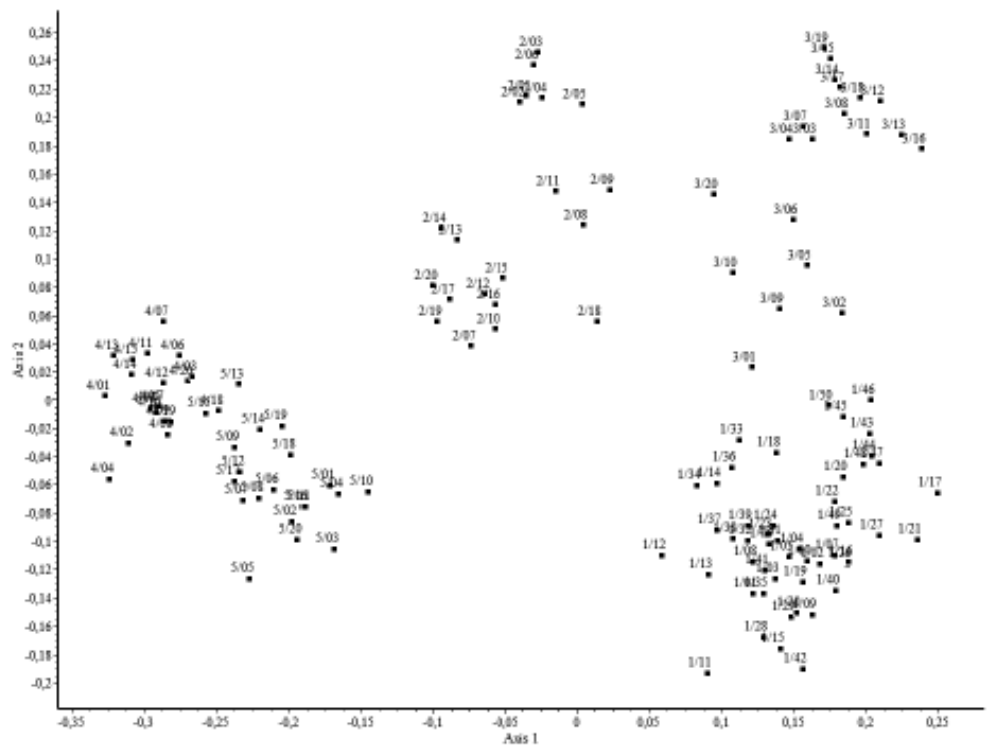

b)

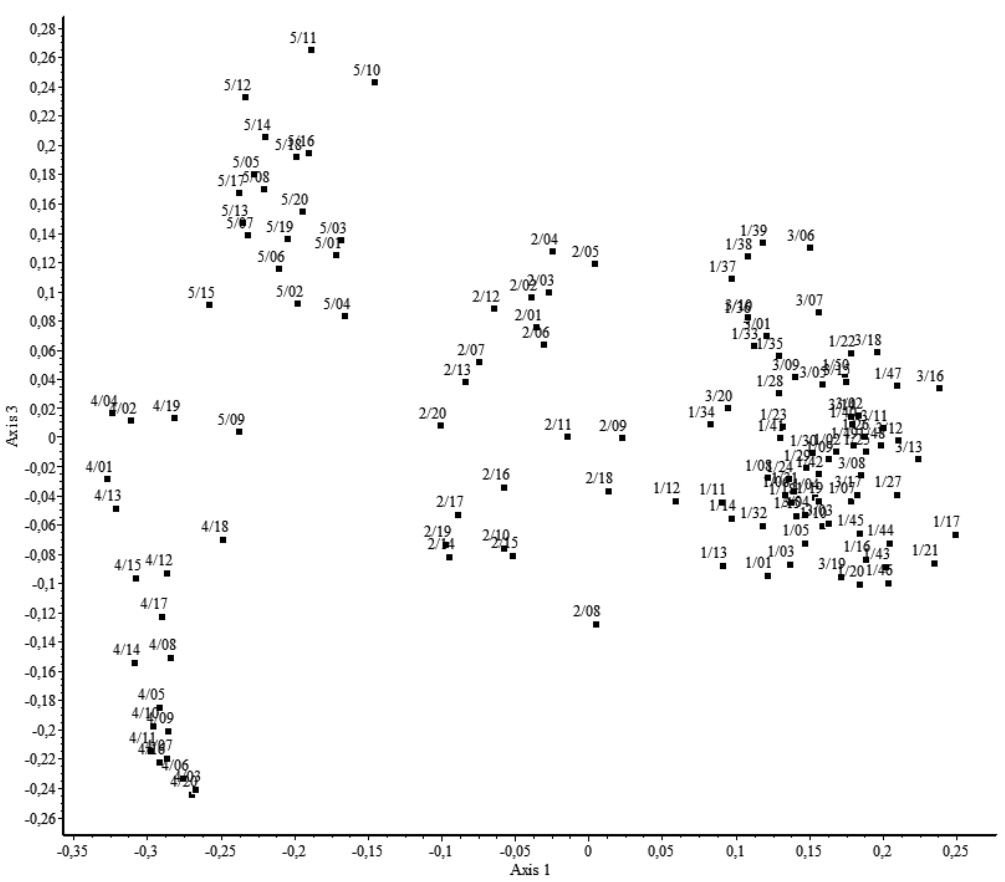

11. ábra. A cönológiai felvételek bináris ordinációs diagramja (hasonlósági index: Baroni-UrbaniBuser; ordinációs módszer: főkoordináta-analízis) a) 1. és 2. tengely; b) 1 . és 3. tengely.

Fig. 11. Binary ordination diagmram of the relevés (similarity coefficient: Baroni-Urbani-Buser; ordination method: principal coordinates analysis) a) axis 1 and 2; b) axis 1 and 3. - 1/1-50: Corydali pumilae-Carpinetum, Tolnai-hegyhát (Jelen tanulmány felvételei/relevés in this study). -2/1-20: Corydali pumilae-Carpinetum, Keleti-Bakony (Kevey ined.); 3/1-20: Corydali pumilae-Carpinetum, Velencei-hegység (Kevey et al. 2014); 4/1-20: Asperulo taurinae-Carpinetum, Nyugati-Mecsek (Kevey

in KeVEY és BoRHIdi 1998); 5/1-20: Asperulo taurinae-Carpinetum, Völgység (Kevey ined.). 


\section{Irodalomjegyzék}

BECKING R. W. 1957: The Zürich-Montpellier school of phytosociology. Botanical Review 23: 411-488. https://doi.org/10.1007/bf02872328

BorHidi A. 1961: Klimadiagramme und klimazonale Karte Ungarns. Annales Universitatis Scientiarum Budapestinensis de Rolando Eötvös Nominatae, Sectio Biologica 4: 21-50.

BorHIDI A. 1993: A magyar flóra szociális magatartás típusai, természetességi és relatív ökológiai értékszámai. Janus Pannonius Tudományegyetem, Pécs, 95 pp.

BoRHIDi A. 1995: Social behaviour types, the naturalness and relative ecological indicator values of the higher plants in the Hungarian Flora. Acta Botanica Hungarica 39: 97-181.

Borhidi A., KeVEy B. 1996: An annotated checklist of the Hungarian plant communities II. In: Borhidi A. (ed.): Critical revision of the Hungarian plant communities. Janus Pannonius University, Pécs, pp. 95-138.

Borhidi A., Kevey B., Lendvai G. 2012: Plant communities of Hungary. Akadémiai Kiadó, Budapest, $544 \mathrm{pp}$.

Braun-BlanQuet J. 1964: Pflanzensoziologie Grundzüge der Vegetationskunde (3rd ed.). Springer Verlag, Wien-New York, 865 pp.

Horváth F., Dobolyi Z. K., Morschhauser T., Lökös L., Karas L., Szerdahelyi T. 1995: Flóra adatbázis 1.2. Taxon-lista és attribútum állomány. MTA Ökológiai és Botanikai Kutatóintézete, Vácrátót, $267 \mathrm{pp}$.

IsSLER E. 1931: Les associations silvatiques haut-rhinoises. Bulletin de la Société Botanique de France 78: 62-141. https://doi.org/10.1080/00378941.1926.10832847

JAKUCS P. 1967: Gedanken zur höheren Systematik der europäischen Laubwälder. Contribuții Botanice, Cluj-Napoca 1967: 159-166.

Kevey B. 2008: Magyarország erdőtársulásai (Forest associations of Hungary). Die Wälder von Ungarn. Tilia 14: 1-488. (+ CD-adatbázis: 244 ábra +230 táblázat).

KeVEy B., BoRHIDI A. 1998: Top-forest (Aconito anthorae-Fraxinetum orni) a special ecotonal case in the phytosociological system (Mecsek mts, South Hungary). Acta Botanica Academiae Scientiarum Hungaricae 41: 27-121.

Kevey B., HirmanN, A. 2002: „NS” számítógépes cönológiai programcsomag. In: Aktuális flóraés vegetációkutatások a Kárpát-medencében V. Pécs, 2002. március 8-10. (Összefoglalók), p. 74.

Kevey B., Horváth A., Lendvai G., Simon Gy. 2018: A Tolnai-hegyhát zárt lösztölgyesei (Pulmonario mollis-Quercetum roboris Kevey 2008). Botanikai Közlemények 105(2): 269-284. + Elektronikus mellékletek (E1-E5 táblázat). https://doi.org/10.17716/BotKozlem.2018. 105.2.269

Kevey B., Lendvai G., Simon Gy. 2014: A Velencei-hegység gyertyános-tölgyesei (Corydali cavaeCarpinetum Kevey 2008). Kanitzia 21: 219-244.

KIRÁlY G. (szerk.) 2009: Új magyar füvészkönyv. Magyarország hajtásos növényei. Határozókulcsok. Aggteleki Nemzeti Park Igazgatóság, Jósvafö, 616 pp.

LUQUET A. 1926: Essai sur la geographie botanique de l'Auvergne. Les associations végétales du Massif des Monts-Dores. Geographie Botanique de l'Auvergne. Les Presses Universitaires de France, Paris, pp. 1-263.

Mucina L., Grabherr G., Wallnöfer S. (eds.) 1993: Die Pflanzengesellschaften Österreichs III. Wälder und Gebüsche. Gustav Fischer, Jena - Stuttgart - New York, 353 pp.

Oberdorfer E. 1992: Süddeutsche Pflanzengesellschaften IV. A. Textband. Gustav Fischer Verlag, Jena - Stuttgart - New York, 282 pp. 
PawŁowski B., SokoŁowski M., Wallisch K. 1928: Die Pflanzenassoziationen des Tatra-Gebirges VII. Die Pflanzenassoziationen und die Flora des Morskie Oko-Tales. Bulletin International de l'Academie Polonaise des Sciences et des Lettres, Classe des Sciences Mathématiques et Naturelles; Série B: Sciences Naturelles, Cracovie, Suppl. 1927: 205-272.

PIllich F. sen. 1927: Adatok Tolnavármegye flórájához. Magyar Botanikai Lapok 26: 94-97.

PIllich F. jun. 1930a: Simontornya és környéke flórája (1921-1930). Pázmány Péter Tudományegyetem Bölcsészeti Kar, Budapest (kézirat), 74 pp.

Pillich F. jun. 1930b: „Simontornya és környéke flórája”-nak gyógyszerészeti vonatkozásai. Gyógyszerészhallgatók Értesítője 2(6-8): 17-32.

Pillich F. jun. 1930c: A Satureja Pillichiana J. Wagn. jellemzése. Botanikai Közlemények 27 (5-6): $105-111$.

PodAni J. 2001: Syn-Tax 2000 Computer programs for data analysis in ecology and systematics. Scientia, Budapest, $53 \mathrm{pp}$.

Soó R. 1964, 1966, 1968, 1970, 1973, 1980: A magyar flóra és vegetáció rendszertani-növényföldrajzi kézikönyve I-VI. Akadémiai Kiadó, Budapest.

VLIEGER J. 1937: Aperçu sur les unités phytosociologiques supérieures des Pays-Bas. Nederlandsch Kruidkundig Archief 47: 335-353.

Elektronikus melléklet: E1-E6. táblázatok

Electronic supplement: Tables E1-E6.

E1. táblázat. Corydali pumilae-Carpinetum felvételek.

Table E1. Corydali pumilae-Carpinetum relevés.

E2. táblázat. Felvételi adatok I.

Table E2. Data of the relevés I.

E3. táblázat. Felvételi adatok II.

Table E3. Data of the relevés II.

E4. táblázat. Karakterfajok aránya. Cp: Corydali pumilae-Carpinetum (jelen tanulmány felvételei), PQ: Pulmonario mollis-Quercetum roboris (KEVEY et al. 2018)

Table E4. Percentage of characteristic species. Cp: Corydali pumilae-Carpinetum (relevés in this study), PQ: Pulmonario mollis-Quercetum roboris (KEVEY et al. 2018)

E5. táblázat. Flóraelemek aránya. Cp: Corydali pumilae-Carpinetum (jelen tanulmány felvételei), PQ: Pulmonario mollis-Quercetum roboris (KEVEY et al. 2018). Table E5. Percentage of floristic elements. Cp: Corydali pumilae-Carpinetum (relevés in this study), PQ: Pulmonario mollis-Quercetum roboris (KEVEY et al. 2018). 
E6. táblázat. A Tolnai-hegyhát gyertyános-tölgyeseinek és zárt lösztölgyeseinek differenciális fajai. Cp: Corydali pumilae-Carpinetum (jelen tanulmány felvételei), PQ: Pulmonario mollis-Quercetum roboris (KEVEY et al. 2018).

Table E6. Differential species in the oak-hornbeam forests and closed oak forests in the Tolnai-hegyhát. Cp: Corydali pumilae-Carpinetum (relevés in this study), PQ: Pulmonario mollis-Quercetum roboris (KEVEY et al. 2018).

\title{
Oak-hornbeam forests in the Tolnai-hegyhát, Hungary (Corydali pumilae-Carpinetum Kevey 2008)
}

\author{
B. KEVEY ${ }^{1}$, A. HORVÁTH ${ }^{2}$, G. LENDVAI ${ }^{3}$ \\ ${ }^{1}$ Department of Ecology, University of Pécs, H-7624 Pécs, Ifjúság útja 6, Hungary; \\ keveyb@gamma.ttk.pte.hu \\ ${ }^{2}$ Vak Bottyán Általános Iskola és Gimnázium, H-7081 Simontornya, Hunyadi u. 15, \\ Hungary; horvath.a.zs@gmail.com \\ ${ }^{3} \mathrm{H}-7000$ Sárbogárd, Tompa Mihály u. 38/C, Hungary; gaborlendvai@hotmail.com
}

Accepted: 7 May 2019

Key words: forest vegetation on loess, southwestern Hungary, syntaxonomy.

We studied the phytosociological characteristics of the hornbeam forests in the Tolnai Hegyhát, an area in the northeastern part of Southern Transdanubia. Phytosociologically, the hornbeam-dominated stands in the study area significantly differ from the closed oak forests (Pulmonario mollis-Quercetum roboris) in the high proportion of Fagetalia species as well as the high proportion of European species, as opposed to the high proportion of Quercetea pubescentipetraeae species and sub-Mediterranean and continental species in the closed oak forests. These hornbeam forests are more similar to the hornbeam forests growing in the Transdanubian Mountain Range than those in Southern Transdanubia. We identified these hornbeam forests with the "Corydali pumilae-Carpinetum Kevey 2008” association within the Carpinenion betuli Issler 1931 suballiance. 